Research paper

\title{
Incorporation of paper sludge in clay brick formulation: Ten years of industrial experience
}

\author{
J.A. Cusidóa \\ L.V. Cremades ${ }^{\mathrm{b}}$ \\ lazaro.cremades@upc.edu \\ C. Soriano ${ }^{c}$ \\ M. Devant ${ }^{\mathrm{a}}$
}

${ }^{a}$ Departament de Física i Enginyeria Nuclear, Universitat Politècnica de Catalunya, Pere Serra, 1-15, 08193 Sant Cugat del Vallès ${ }_{2}$ Barcelona, Spain

'Departament de Projectes d’'Enginyeria, Universitat Politècnica de Catalunya, Avda.

Diagonal, 647, 08028 Barcelona, Spain

'International Center for Numerical Methods in Engineering (CIMNE), C/ Gran Capità, s/n, Campus Nord UPC, Ed, 08034 Barcelona, Spain

${ }^{\square}$ Corresponding author. Tel.: + 34934011750.

\begin{abstract}
The large amounts of sewage sludge (11 million tonnes in Europe in 2005) produced in paper manufacturing plants require the introduction of recycling and/or alternative recovery solutions to minimize the amounts of generated waste, such as its use in soil remediation or in the cement industry. A feasible alternative to valorize that waste is the use of paper sludge as raw material in the production of structural ceramic or clay bricks.Previous studies tried to incorporate sewage sludge from different sources into ceramic matrices, unfortunately with little success in the final result for most types of sludge. However, those experiments carried out using as additive sludge from the paper industry succeeded in producing a material suitable for the red ceramic industry.In this paper, binary mixtures of clay and paper sludge under different formulations were produced and and their physico-chemical properties were studied. Increasing the paper sludge content in the clay mixture provides the material with improved properties regarding its thermal and acoustic insulation, but in turn it decreases its mechanical strength. However, this fragility of the material is compensated by an increased ductility. Regarding metal leaching, the studied ceramics have no environmental restrictions as far as their use as building material is concerned, as the obtained results were virtually identical to those for the blank samples (100\% clay). Results showed that the presence of dichloromethane $\left(373.2 \mu \mathrm{g} \mathrm{m}^{-3}\right)$ and propanone $\left(61.2 \mu \mathrm{g} \mathrm{m}^{-3}\right)$ in the
\end{abstract}


samples with added sludge was relatively relevant with respect to concentrations in samples made of $100 \%$ clay. All monocyclic aromatics detected showed a concentration level far below theiredour odor threshold. In general, thus, it can be concluded that volatile organic eompoundscompound (VOGSVOC) emissions during firing of the new ceramic material do not involve any particular problem. Finally, the experience obtained after more than 10 years of industrial production of this new mixed ceramic product was also analyzed. This analysis allowedto confirm-confirmation that clay brick production with incorporation of paper sludge waste is a feasible solution from a technical point of view. As a key outcome, this fact has helped to reduce the reduction in a large proportion the amount of sludge produced by the Spanish paper industry ending up in landfills.

Keywords: Paper sludge; Clay ceramics; Leaching; Gaseous emissions; Industrial production

\section{Introduction}

The manufacturing process of paper, and that of tissue paper in particular, produces a sludge residue, which is the final product of the process after the treatment of waste waters at sewage treatment stations.

In 2005, the total production of paper in Europe was 99.3 million tonnes, generating 11 million tonnes of waste and representing about $11 \%$ of the world paper production. The production of recycled paper during the same period was 47.3 million tonnes, generating 7.7 million tonnes of solid waste and representing $16 \%$ of the total production of this material (Monte et al., 2009). In the case of Spain, the existing 86 paper industry plants consume 2 million tonnes of cellulose per year. The consumption of paper per inhabitant and year is on the order of $170 \mathrm{~kg}$, resulting in 1.6 -Mt of sludge produced every year by this industrial sector.

Two types of sludge are produced in the paper industry: sewage sludge and deinking sludge. Sometimes, these wastes are mixed and are usually disposed of in landfills, with the consequent risk of contamination of soil and land degradation. Various alternatives have been considered for final use of this residue, with energy recovery and production of materials for construction standing out (Pera and Amrouz, 1998; Pera et al., 2001; Mymrin et al., 2009).

Sludge resulting from the paper industry contains roughly 50\% in mass of water, as a hydrophilic residue, $30 \mathrm{wt} . \%$ of cellulose plus kaolin and calcite (calcium carbonate), and, in a more minority proportion, organic compounds and heavy metals. Currently, over $95 \%$ of the paper production processes are free of chlorine, since 
recovery is promoted (Monte et al., 2009). The description and characterization of the sludge from the paper industry in general, as well as the techniques used to identify it can be found in Likon and Trebse (2012).

The high load of clay (kaolin) and high interstitial water content of paper industry sludge (compared to other types of sewage sludge) does-do not make it suitable for energy recovery, due to its low calorific value. On the other hand, its high content in organic matter (cellulose) makes it unsuitable for disposal in landfills (Council Directive, 1999). This sludge is chemically and microbiologically stable (without emitting edoufodors and/or toxic compounds such as $\mathrm{H}_{2} \mathrm{~S}, \mathrm{NH}_{3}$ or butyric acid), and can be preserved for a long time at room temperature (Cernec et al., 2005).

Since the early works of Tay (1987), many authors have reported studies related to the production of clay bricks with binary mixtures (Berman, 1982;Wiebusch et al., 1998; Liew et al., 2004; Jordan et al., 2005; Monteiro et al., 2008; Loutou et al., 2013) and ternary mixtures (Chiang et al., 2009; Montero et al., 2009; Devant et al., 2011). These studies often mention the addition of sewage sludge from Waste Water Treatment Plants (WWTP) in these mixtures, although with the same type of dehydrated sludge and even sewage sludge ash (Lin and Weng, 2001). Other eeramics-ceramic production processes described in the literature discuss the use of sludge from the paper industry (Demir et al., 2005) or from the galvanic and oil industry (Monteiro and Vieira, 2005). More recently, pellets produced from WWTP dried sludge have also been used in the redeeramies-ceramic industry (Qi et al., 2010), while there are also some experiences regarding its use for the production of concrete blocks (Kaosol, 2010).

The production of clay ceramic with incorporation of 5-15 wt.\% paper sludge has been reported by different authors (Ismail et al., 2010; Chemani and Chemani, 2013). These works pointed out that the presence of organic fibers increases the porosity of the matrix supporting the manufacture of bricks. Ultimately, this fact results in a reduction in the need of fuel in furnaces, favoring both sintering and drying.

Regarding the addition of paper sludge, the available literature is scarce. Nevertheless, it is worthwhile to mention the works by Asquini et al. (2008) andChemani and Chemani (2013), which added glass cullet to the mixture with clay and paper sludge. Maschio et al. (2009) described the production of tiles made from paper mill sludge, glass cullet and clay, with high content in sludge (60 wt.\%), although the sludge was previously incinerated, resulting in a final ceramic product suitable for industrialization. Other works (Toya et al., 2006) reported on the preparation of glass-ceramics from mixtures of wastes generated from refining of silica 
sand___kaolin clay and paper sludge ash mixed in mass ratios of 55/45 melted at $1400{ }^{\circ} \mathrm{C}$ to obtain glasses with satisfactory results.

Thermal destruction of paper sludge, and in general of solid waste, seems to be the main problem to overcome for the generalization of its use as raw material (Lee and Bae, 2009). Indeed, the presence of organic waste compounds results in the emission of gaseous products through the furnace stack during firing.

This paper describes the preparation and characterization of clay bricks made with binary mixtures of clay and paper sludge. It also presents the results and lessons learned after more than 10 years of successful industrial application of this process by several Spanish ceramic companies.

\section{Materials and methods 2.1 Selection of raw materials}

For this study, local clays commonly used in the eeramics-ceramic industry in Catalonia (NE Spain) were selected. More precisely, the chosen clay used in the experiments was from El Papiol (15 km northwest from Barcelona). This particular clay is characterized as calcareous or loamy (Table 1), and is representative of the types of clay found in the area of Barcelona, where there is a significant presence of the ceramic industry.

Table 1 Qualitative mineral content of the clay used in the tests.

\begin{tabular}{|l|l|}
\multicolumn{1}{|c|}{ Mineral } & \multicolumn{2}{c}{ Qualitative presence } \\
\hline$\alpha$-quartz & $* * * *$ \\
\hline Calcite & $* *$ \\
\hline Mica & $* *$ \\
\hline Chlorite & $*$ \\
\hline Feldspar & $*$ \\
\hline Dolomite & $*$ \\
\hline Goethite & $*$ \\
\hline Hematite & \\
\hline
\end{tabular}

Note: one asterisk $(*)$ means a presence of $6-6.5 \mathrm{wt} . \%$ of mineral; $* * \approx 12-13 \mathrm{wt} . \%$; $* * * \approx 24-26 \mathrm{wt} . \%$.

As for the sludge, its origin was a tissue paper industry considered as representative of the sector in Catalonia (Table 2). It is located in La Riba (Tarragona), $100 \mathrm{~km}$ southwest from Barcelona. The chemical analysis of this sludge is shown in Table 3. Compared to WWTP sludge (which mineralogical and chemical 
composition can be very variable according to socio-economic characteristics of the population served by the WWTP), the properties of sludge from the paper industry have a lower variability. Thus, the use of a single type of paper sludge for this study can be considered as sufficient as far as the representation of the industry in the region.

Table 2 Properties of the sludges used in the tests.

\begin{tabular}{|l|l|}
\hline Average humidity (wt.\%) & $58.6 \pm 0.2$ \\
\hline Organic matter (wt.\%) & $24 \pm 1$ \\
\hline Inorganic matter (wt.\%) & $17.4 \pm 0.5$ \\
\hline $\mathrm{pH}$ & $7.6 \pm 0.3$ \\
\hline Conductivity $\left(\mu \mathrm{S}-\mathrm{cm}^{-1}\right)^{\mathrm{a}} 1$ & $550-=1103$ \\
\hline
\end{tabular}

a-Obtained from leachate by following the norm DIN 38414S4.

Table 3 Chemical characterization of the sludge used in the tests.

\begin{tabular}{|c|c|}
\hline Species & $\mathrm{mg} \mathrm{kg}^{-1}$ of dry sludge \\
\hline \multicolumn{2}{|c|}{ According to leaching test:- } \\
\hline $\mathrm{Na}^{+}$ & 220 \\
\hline $\mathrm{Cl}_{--}^{-}$ & 130 \\
\hline $\mathrm{Mg}^{2+}$ & 298 \\
\hline $\mathrm{NO}_{3}=$ & 1.18 \\
\hline $\mathrm{Ca}^{2+}$ & 2530 \\
\hline $\mathrm{NO}_{2}=-$ & $<5$ \\
\hline $\mathrm{K}^{+}$ & 5.9 \\
\hline $\mathrm{F}^{-}-$ & $<5$ \\
\hline $\mathrm{PO}_{4}{ }^{3}=$ & 87 \\
\hline $\mathrm{SO}_{4}^{2}=$ & 1470 \\
\hline TOC & 3989 \\
\hline \multicolumn{2}{|c|}{ Analysis of total metals in the solid residue:- } \\
\hline $\mathrm{Fe}$ & 1615 \\
\hline Al & 14,400 \\
\hline $\mathrm{Ba}$ & 172 \\
\hline
\end{tabular}




\begin{tabular}{|c|c|}
\hline Species & mg kg=1 of dry sludge \\
\hline $\mathrm{Na}$ & 552 \\
\hline $\mathrm{Mg}$ & 1654 \\
\hline $\mathrm{Ca}$ & 85,071 \\
\hline K & 77.5 \\
\hline $\mathrm{N}$ total & 2461 \\
\hline $\mathrm{Pt}$ & 1.9 \\
\hline \multicolumn{2}{|c|}{ Analysis of extractable metals in the solid residue according to norm ISO CD11566: } \\
\hline $\mathrm{Cd}$ & n.d. \\
\hline Zn & 231 \\
\hline $\mathrm{Ni}$ & 6 \\
\hline $\mathrm{Ti}$ & 33 \\
\hline $\mathrm{Cu}$ & 33 \\
\hline $\mathrm{Mn}$ & 34 \\
\hline $\mathrm{Cr}$ & 17 \\
\hline $\mathrm{Hg}$ & 0.2 \\
\hline $\mathrm{Pb}$ & 37 \\
\hline As & n.d. \\
\hline $\mathrm{Al}$ & 19,500 \\
\hline
\end{tabular}

\subsection{Production of samples for testing}

The first step of the study consisted of the production of a set of ceramic pieces in order to carry out several tests. Up to 30 ceramic pieces were prepared in the laboratory from a mixture of only $10 \mathrm{~kg}$ (by comparison, an industrial test would require the preparation of a minimum of $1000 \mathrm{~kg}$ of material).

In the first stage of the production of the samples, the two components, i.e. crushed clay and paper sewage sludge, were mixed with water sprayed as fine droplets in a 10-liter mixing bowl (Controls, model BT72). The mixture was moistened until the optimal humidity to get a homogeneous material was reached. The rheological characteristics of paper sludge made this operation difficult due to its extreme plasticity. It should be pointed out that sludge was used as is. If it had previously been dried to 
remove interstitial water, the process would become unfeasible from an economic point of view.

During the second stage, the mixture was extruded under high-pressure (10 bar approx.) (extruder Verdés, model 050-C) to obtain rectangular bars that were cut into test pieces of 5 or $12 \mathrm{~cm}$ long to conduct compression tests. Cylindrical pieces of $5 \mathrm{~cm}$ diameter and $1.5 \mathrm{~cm}$ height were used for thermal conductivity tests. Rectangular pieces of $12 \mathrm{~cm}$ were used to study other ceramic properties, such as retraction, water absorption, density, porosity, etc.

In the third and last stage of production of the test pieces, they were dried at

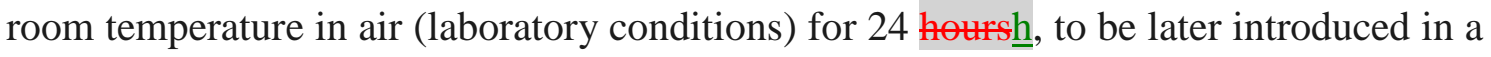
stove at $100{ }^{\circ} \mathrm{C}$ (Raypa, model DO-40) for another 24 hoursh.

\subsection{Sintering}

All pieces were sintered in a single process to ensure equal thermal treatment. Test samples were fired in a propane oven (Formagas, model HG-150) at a heating rate of $160{ }^{\circ} \mathrm{C} \mathrm{h}^{=1}$, from room temperature to $980^{\circ} \mathrm{C}$. Next, test samples were kept at the oven at maximum temperature for 3 more hours, and remained inside 12 more hours until cooled down to room temperature. At this point, the ceramic pieces were taken out of the oven.

\subsection{Testing}

Test specimens made of binary mixture as specified in the previous section were compressed until rupture. Mechanical resistance was measured with two Instron servohydraulic machines, models 1341 and 1342; uploading speed of piston was $0.11 \mathrm{MPa} \min ^{-1}$. The number of samples was 30; each had the shape of a parallelepiped of $5 \mathrm{~cm}$ long and $1.5 \mathrm{~cm}$ square. The test was carried out following the standard UNE 67-026-94 (1994).

The thermal conductivity of the pieces was measured using a Holometrix TCA LT-A heat-flow meter. To run this test, a thermal flow was applied at a constant rate through a cylindrical sample of approximately $5 \mathrm{~cm}$ in diameter and $1.5 \mathrm{~cm}$ thick, where thermocouples were placed at both sides. The number of samples for this test was 5 .

Water absorption (over 24 h), $\mathrm{w}_{\mathrm{a}}$, was calculated from Eq. (1):

$$
w_{\mathrm{a}}=\frac{\mathrm{m}_{\mathrm{w}}-\mathrm{m}_{\mathrm{d}}}{\mathrm{m}_{\mathrm{d}}}
$$

where $m_{w}$ is the mass of the $1 \mathrm{~h}$ saturated sample, and $m_{d}$ is the mass of the dry sample, following APHA methods (APHA, 1992). 
When a new material or product is obtained from hazardous wastes it must undergo strict testing to ensure its safety towards end users and the environment, and to asses-assess any possible associated health risks.

The most popular test to assess these risks is the leaching test. Leaching studies have raised some scientific controversy about the methodology they should follow, and particularly about the most suitable method for the chemical extraction of leachates. This fact has resulted in a large number of scientific publications (Wiebusch et al., 1998) and the promulgation of several EU directives to harmonize existing methodologies (in particular those for structural and construction materials (Van der Sloot, 2001)).

In this study, leaching tests were performed according to the European standard EN 12457-1 (2002) for the study of leachates in waste materials and sludge. Leaching tests were performed with $8 \mathrm{~cm}$ long samples. The number of samples was 12 . Measurements of volume, surface area and mass were carried out in triplicate.

Gaseous emissions were analyzed during the process of production of the ceramic material. The analyzed pollutants were suspended particles, sulfur dioxide, carbon monoxide, hydrochloric acid, hydrofluoric acid, metals ( $\mathrm{Pb}, \mathrm{Cr}, \mathrm{Cu}, \mathrm{Ni}, \mathrm{Co}, \mathrm{V}$, As, Tl, Sb, Sn, Mn, Zn, Cd), total organic carbon, nitrogen oxides (as ppm of $\mathrm{NO}_{2}$ ), and opacity in the Bacharach scale. Simultaneously, the following emission parameters were measured: oxygen (vol.\%volume), carbon dioxide (vol.\%-volume), gas velocity ( $\mathrm{m} / \mathrm{s}$ ) and gas flow_rate in dry basis $\left(\mathrm{Nm}^{3} \mathrm{~h}^{-1}\right)$. All measurements at the furnace were taken $3.4 \mathrm{~m}$ below the top of the chimney, in agreement with the minimum requirements established by the EPA (EPA, 1994). The diameter of the chimney at the sampling point was 1.4 metersm. Details on the equipment and methodology used in the tests can be found in Appendix A.

\section{Results and discussion}

\subsection{Experimental results}

X-ray diffractometric analysis of the afore-mentioned sludge evidenced the presence of calcite, kaolinite and cellulose (Fig. 1). The main reactions occurring in a clay with carbonate (calcite) during its cooking process are described below (Brownell, 1976; Hajjaji and Kacim, 2004; Sutcu and Akkurt, 2009):

At $573{ }^{\circ} \mathrm{C}$, phase transition from $\alpha-\mathrm{SiO}_{2}$ to $\beta-\mathrm{SiO}_{2}$.

Between 850 and $900{ }^{\circ} \mathrm{C}$, dehydroxylation of illite and clinochlore mineral. 
At $900{ }^{\circ} \mathrm{C}$ carbonates decompose. Their oxides $\mathrm{CaO}$ and $\mathrm{MgO}$ react with alumina and silica to form gehlenite, $\mathrm{Ca}_{2} \mathrm{Al}\left(\mathrm{AlSiO}_{7}\right)$, anorthite, $\mathrm{CaAl}_{2} \mathrm{Si}_{2} \mathrm{O}_{8}$, and diopside, $\mathrm{CaMg}\left(\mathrm{SiO}_{3}\right)_{2}$.

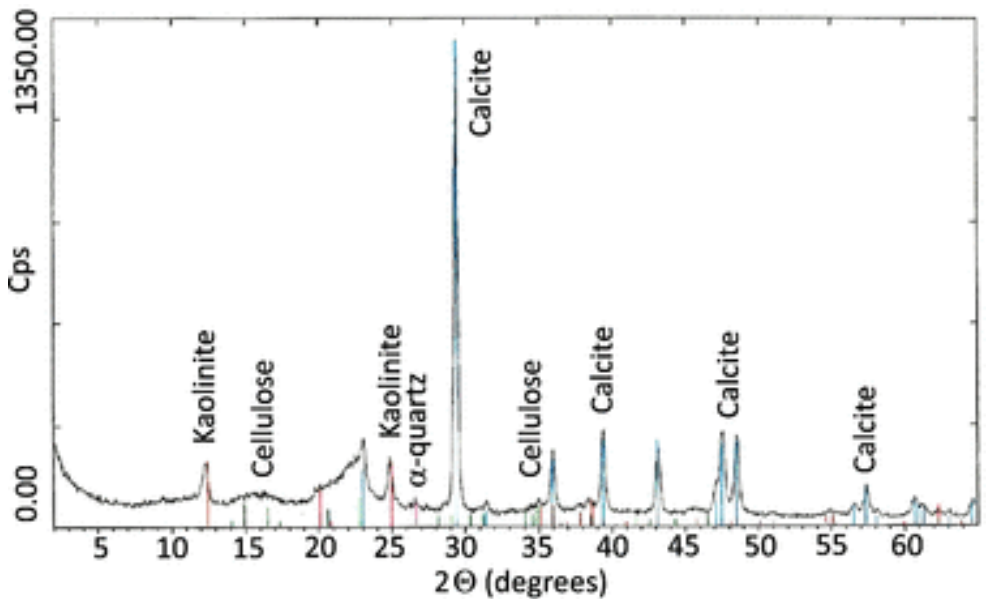

Fig. 1 X-ray diffraction diagram corresponding to the crystalline phases present in the sludge from the paper industry used in this work.

In agreement with the results found in Jordan et al. (2005), the mineral phases identified in the ceramic with added sludge were gehlenite, anorthite, wollastonite, diopside and spinel, being very similar to those identified in a standard clay brick (100\% clay) (Brownell, 1976).

Studies on the pozzolanic properties of paper sludge indicate that, aroundthe $700{ }^{\circ} \mathrm{C}$, kaolinite becomes reactive amorphous metakaolinite, which, together with other components of the sludge (muscovite, talc, calcium carbonate and cellulose) act as activators of the metakaolinite in the pozzolanic reaction contributing to the ceramization process of the whole mix of raw materials (Vigil de la Villa et al., 2007).

The mechanism of formation of porosity in the new ceramic material was closely related to the combustion process, which took place in several stages (Tang et al., 2003; Salomãoa et al., 2011). First, dehydration and devolatilization occurred from the surface to the interior of the bulk material. Next, steam and volatile compounds produced in the process associated to-with the thermal destruction of cellulose expanded from the interior, resulting in the formation of pores. Finally, volatile compounds and syngas burnt on the material surface.

The high calcite content (around 50 wt.\%) and dolomite in paper sludge favored the formation of the glass phase during sintering. They act similarly to the calcium feldspar in clays, producing a kind of vitrification of the material (El Yakoubi et al., 2006). CaO particles have a porous structure that helps to decrease the thermal 
conductivity. It also reduces the shrinkage of the final piece to $1-2 \%$ compared with $3 \%$ in normal ceramic pieces without wastes (Sutcu and Akkurt, 2009). The structural features are diminished as a result of interstitial water sludge (Chemani and Chemani, 2013).

Results of the compression strength tests in all cases far exceeded the $10 \mathrm{MPa}$ (Table 4), the minimum bulk mechanical strength to compression recommended for a ceramic material to be used in buildings. The average value of compression strength obtained for the whole set of test piece with percentage of sludge between $0 \%$ and 25 wt.\% was $39 \mathrm{MPa}$.

Table 4 Results of compression strength (MPa) tests for specimens of clays from El Papiol. Errors correspond to the standard deviation of the 6 results obtained for each percentage of sludge in the clay mixture.

\begin{tabular}{|l|l|}
\hline $\begin{array}{c}\text { Percentage of sludge } \\
\text { (wt.\%) }\end{array}$ & $\begin{array}{c}\text { Compression strength } \\
\text { (MPa) }\end{array}$ \\
\hline 0 & $47 \pm 8$ \\
\hline 5 & $49 \pm 9$ \\
\hline 10 & $38 \pm 8$ \\
\hline 15 & $42 \pm 4$ \\
\hline 20 & $34 \pm 5$ \\
\hline 25 & $24 \pm 3$ \\
\hline
\end{tabular}

Thermal conductivity decreased as the concentration of paper sludge increased (Table 5). For a percentage of 15 \%t. \%wt.\% sludge, (i.e. maximum percentage recommended in this work, in balance with the other rheological properties of the product), thermal conductivity was reduced by $16 \%$. For an extreme percentage of 25 wt.\% sludge, thermal conductivity decreased 38\%, although in this case the final product could not lead to a commercial ceramic clay. This decrease is attributed to the porosity provided by the organic components of sludge such as cellulose, among others. Although remarkable, it is not significant as to define the product as a thermal insulator of great capacity.

Table 5 Values of thermal conductivity $\left(\mathrm{W} \mathrm{m}^{-1} \mathrm{~K}^{-1}\right.$ ) at $20^{\circ} \mathrm{C}$ obtained for each percentage of sludge in the clay mixture.

\begin{tabular}{|c|c|}
\hline $\begin{array}{l}\text { Percentage of sludge } \\
\text { (wt.\%) }\end{array}$ & $\begin{array}{l}\text { Thermal conductivity } \\
\qquad\left(\mathrm{W} \mathrm{m}^{-1} \mathrm{~K}^{-1}\right)\end{array}$ \\
\hline 0 & 0.69 \\
\hline
\end{tabular}




\begin{tabular}{|l|l|}
\hline $\begin{array}{c}\text { Percentage of sludge } \\
\text { (wt.\%) }\end{array}$ & \multicolumn{1}{c|}{$\begin{array}{c}\text { Thermal conductivity } \\
\left(\mathrm{W} \mathrm{m}^{-1} \mathrm{~K}^{-1}\right)\end{array}$} \\
\hline 5 & 0.72 \\
\hline 10 & 0.66 \\
\hline 15 & 0.58 \\
\hline 20 & 0.49 \\
\hline 25 & 0.43 \\
\hline
\end{tabular}

Results of the water absorption tests showed a significant increase of weight in the ceramics with added sludge (Table 6). The explanation of thisbehaviour behavior could be related to the fact that for the most part of the organic fraction of the sludge has become open porosity. These values represent a $300 \%$ increase in water absorption with respect to absorption rates of standard ceramics without additives.

Table 6 Increase of weight (\%) of specimens due to water absorption after 24 hourshfollowing the standard UNE 67-027.

\begin{tabular}{|c|c|}
\hline $\begin{array}{c}\text { Percentage of sludge } \\
\text { (wt.\%) }\end{array}$ & $\begin{array}{l}\text { Increase of weight } \\
\text { (\%) }\end{array}$ \\
\hline 0 & $8.8 \pm 0.4$ \\
\hline 5 & $11.5 \pm 0.3$ \\
\hline 10 & $13.4 \pm 0.3$ \\
\hline 15 & $15.5 \pm 0.7$ \\
\hline 20 & $21.6 \pm 0.2$ \\
\hline 25 & $26.6 \pm 0.2$ \\
\hline
\end{tabular}

Norm EN 12457-1 (2002) specifies that building materials are classified, according to their leachability test, into two categories: materials without environmental restrictions (leaching limit $<\mathrm{U}_{1}$ ); and materials having a restricted use (leaching limit $<\mathrm{U}_{2}$ ) (Table 7). Materials, which total leachability is comprised between values $\mathrm{U}_{1}$ and $\mathrm{U}_{2}$, are not submitted to any environmental restriction regarding its use in the building industry, although they will require proper disposal at the end of their operational lifetime.

Table 7 Leaching test conducted in ceramic material produced with clay from El Papiol, together with leaching limits $U_{1}$ and $U_{2}$ set by the norm EN 12457-1 (2002). Leachate concentrations are expressed as mg m-2; “n.d.” = no detectable concentration with the measuring equipment. 


\begin{tabular}{|c|c|c|c|c|}
\hline Pollutant & 0 wt.\% sludge & 15 wt.\% sludge & $\begin{array}{c}\mathrm{U}_{1} \\
\operatorname{limit}\end{array}$ & $\begin{array}{c}\mathrm{U}_{2} \\
\text { limit }\end{array}$ \\
\hline As & n.d. & n.d. & 40 & 300 \\
\hline $\mathrm{Ba}$ & n.d. & n.d. & 600 & 4500 \\
\hline $\mathrm{Cd}$ & n.d. & n.d. & 1 & 7.5 \\
\hline Co & n.d. & n.d. & 25 & 200 \\
\hline $\mathrm{Cr}$ & n.d. & n.d. & 150 & 950 \\
\hline $\mathrm{Cu}$ & n.d. & n.d. & 50 & 350 \\
\hline $\mathrm{Hg}$ & n.d. & n.d. & 0.4 & 3.0 \\
\hline Mo & n.d. & n.d. & 15 & 95 \\
\hline $\mathrm{Ni}$ & n.d. & n.d. & 50 & 350 \\
\hline $\mathrm{Pb}$ & n.d. & n.d. & 100 & 800 \\
\hline $\mathrm{Sb}$ & n.d. & n.d. & 3.5 & 25 \\
\hline Se & n.d. & n.d. & 1.5 & 9.5 \\
\hline Sn & n.d. & n.d. & 25 & 200 \\
\hline V & 78 & 52 & 250 & 1500 \\
\hline $\mathrm{Zn}$ & n.d. & n.d. & 200 & 1500 \\
\hline $\mathrm{Br}^{-2}-$ & 215 & n.d. & 25 & 200 \\
\hline $\mathrm{Cl}^{-}-$ & n.d. & n.d. & 20,000 & 150,000 \\
\hline $\mathrm{F}_{-}^{-}-$ & 212 & n.d. & 1500 & 9500 \\
\hline $\mathrm{SO}_{4}{ }^{2}=-$ & 3471 & n.d. & 250,000 & 200,000 \\
\hline
\end{tabular}

Table 7 shows results of the leaching test performed on the mixture made of 85 wt.\% clay from El Papiol and 15 wt.\% sludge. Results of the leaching tests showed levels well below the limit $U_{1}$. Detectable levels were only found for vanadium (V), bromide $\left(\mathrm{Br}^{-}-\right)$, fluoride $\left(\mathrm{F}^{-}\right)$and sulphate-sulfate $\left(\mathrm{SO}_{4}{ }^{-}{ }^{-}\right)$in the case of the ceramics without additives, but only for $\mathrm{V}$ in the case of the mixture with sludge.

Regarding metal leaching, the studied ceramics have no environmental restrictions as far as their use as building material is concerned, as the obtained results were virtually identical to those for the blank samples (100\% clay). The presence of Cd and $\mathrm{Hg}$ was not detectable in any of the cases, and the results were in agreement with 
the fact that the concentration of heavy metals was similar both in the clay and in the sludge that were used to prepare the mixtures.

Results of the gaseous emissions emission measurements (Table $\underline{9} 9$ ) show an important increase in the level of emission of suspended particulates in the sample with added sludge (11.4 to $200 \mathrm{mg} \mathrm{Nm}^{-3}$ ), while for other parameters, such as $\mathrm{NO}_{\mathrm{x}}$, emissions decreased dramatically (800 to $200 \mathrm{mg} \mathrm{Nm}^{-3}$ ). Emissions of heavy metals remained, as expected, similar for the two samples (blank and with added sludge), since paper sludge does not significantly incorporate these elements into the mixture. From this point of view, adding paper sludge into the ceramic material does not involve any environmental risk. (See Table 8.)

Table 108 Outgassing and offgassing tests applied to ceramic pieces according to ESA PSS-01-702 (1994) and ESA PSS-01-729 (1991), respectively. The clay used in the mixture was the one from El Papiol.

\section{0 wt.\% sludge 15 wt.\% sludge Allowed limit value of the test}

\section{Outgassing test:}

\begin{tabular}{|l|l|l|l|}
\hline Weight loss of material (wt.\%) & 0.054 & 0.095 & 1 \\
\hline Volatile condensed matter (wt.\%) & 0 & 0 & 0.1 \\
\hline
\end{tabular}

\section{Offgassing test:}

\begin{tabular}{|l|l|l|l|}
\hline $\mathrm{CO}\left(\mu \mathrm{g} \mathrm{g}^{-1}\right)$ & $<25$ & $<25$ & $<25$ \\
\hline $\operatorname{TOC}\left(\mu \mathrm{g} \mathrm{g}^{-1}\right)$ & $<100$ & $<100$ & $<100$ \\
\hline
\end{tabular}

Table $\underline{8} 9$ Inorganic air pollutants emitted during the firing of ceramic pieces. Comparison between ceramics made of clay from El Papiol with 0\% sludge (blank) and 15 wt.\% sludge.

\begin{tabular}{|c|c|c|c|c|}
\hline \multirow[t]{2}{*}{ Pollutant } & \multicolumn{2}{|c|}{0 wt.\% sludge } & \multicolumn{2}{|c|}{15 wt.\% sludge } \\
\hline & $\begin{array}{c}\text { Temperature } \\
\text { range }\left({ }^{\circ} \mathrm{C}\right)\end{array}$ & $\begin{array}{c}\text { Emission level } \\
\left(\mathrm{mg} \mathrm{Nm}^{-3}\right)^{\mathrm{a}}\end{array}$ & $\begin{array}{l}\text { Temperature } \\
\text { range }\left({ }^{\circ} \mathrm{C}\right)\end{array}$ & $\begin{array}{l}\text { Emission level } \\
\left(\mathrm{mg} \mathrm{Nm}^{-3}\right)^{\mathrm{a}} 1\end{array}$ \\
\hline $\begin{array}{l}\text { Particulate } \\
\text { suspended matter }\end{array}$ & 20--930 & 11.4 & $20-1060$ & 200.0 \\
\hline \multirow[t]{3}{*}{$\mathrm{SO}_{2}$} & $20-500$ & 8.4 & $20--500$ & 11.7 \\
\hline & $500-930$ & $<0.07$ & $500-1060$ & 12.2 \\
\hline & $930-930$ & $<0.07$ & $1060-1060$ & 10.5 \\
\hline $\mathrm{HCl}$ & $20-500$ & 1.0 & $20-500$ & 2.5 \\
\hline
\end{tabular}




\begin{tabular}{|c|c|c|c|c|}
\hline \multirow[t]{2}{*}{ Pollutant } & \multicolumn{2}{|c|}{0 wt.\% sludge } & \multicolumn{2}{|c|}{15 wt.\% sludge } \\
\hline & $\begin{array}{l}\text { Temperature } \\
\text { range }\left({ }^{\circ} \mathrm{C}\right)\end{array}$ & $\begin{array}{l}\text { Emission level } \\
\left(\mathrm{mg} \mathrm{Nm}^{-3}\right)^{\mathrm{a}}\end{array}$ & $\begin{array}{l}\text { Temperature } \\
\text { range }\left({ }^{\circ} \mathrm{C}\right)\end{array}$ & $\begin{array}{c}\text { Emission level } \\
\left(\mathrm{mg} \mathrm{Nm}^{-3}\right)^{a} 1\end{array}$ \\
\hline & $500-930$ & 0.4 & $500-1060$ & 9.3 \\
\hline & $930-=930$ & $<0.07$ & $1060-1060$ & 2.0 \\
\hline \multirow[t]{2}{*}{$\mathrm{HF}$} & 20--930 & 2.82 & 0.09 & 1.48 \\
\hline & $930-930$ & 0.41 & 0.01 & 0.14 \\
\hline \multirow{3}{*}{$\begin{array}{l}\mathrm{NO}_{\mathrm{x}} \text { (expressed as } \\
\mathrm{NO}_{2} \text { ) }\end{array}$} & $20-500$ & 836.0 & $20-500$ & 71.9 \\
\hline & $500-930$ & 865.4 & $500-1060$ & 189.7 \\
\hline & $930-930$ & 715.9 & $1060--1060$ & 279.5 \\
\hline $\mathrm{Pb}$ & 20--930 & $<0.03$ & $20-1060$ & $<0.3$ \\
\hline $\mathrm{Ni}$ & & $<0.006$ & & 1.25 \\
\hline Zn & & 0.93 & & 0.69 \\
\hline $\mathrm{Cu}$ & & $<0.006$ & & $<0.006$ \\
\hline $\mathrm{Cr}$ & & 0.02 & & 2.88 \\
\hline Mn & & $<0.006$ & & 0.25 \\
\hline $\mathrm{Cd}$ & & $<0.006$ & & $<0.006$ \\
\hline $\mathrm{Sb}$ & & $<0.03$ & & n.d. \\
\hline $\mathrm{Tl}$ & & $<0.03$ & & n.d. \\
\hline As & & $<0.03$ & & n.d. \\
\hline Co & & $<0.006$ & & $<0.006$ \\
\hline $\mathrm{V}$ & & $<0.03$ & & $<0.3$ \\
\hline Sn & & $<0.03$ & & $<0.3$ \\
\hline
\end{tabular}

a.-Concentration referred to a content of $11 \%$ oxygen (vol.); n.d. = = not detected.

Volatile organic eompounds-compound (VOGsVOC) concentrations detected in the gaseous emissions during the firing of both, blank ceramic pieces (100\% clay), and ceramic pieces with 15 wt.\% paper sludge are shown inTable 910 . Some Threshold Limit Value__ Time Weighted Average (TLV__TWA) levels and odoufodor detection thresholds are also indicated to facilitate interpretation of the results. 
Table $\underline{910}$ VOCs emitted during the firing of ceramic pieces. Comparison between ceramics made of clay from El Papiol with 0\% sludge (blank) and 15 wt.\% sludge, TLV__TWA values and $\theta$ dourodor detection thresholds according to the American Industrial Hygiene Association (1989). Concentrations are expressed in $\mu \mathrm{g} \mathrm{m}^{-\underline{-3} \text {. }}$.

\begin{tabular}{|c|c|c|c|c|c|}
\hline Family & Species & $\begin{array}{l}0 \text { wt.\% } \\
\text { sludge }\end{array}$ & $\begin{array}{c}15 \text { wt. } \% \\
\text { sludge }\end{array}$ & $\begin{array}{l}\text { TLV-- } \\
\text { TWA }\end{array}$ & OdourOdorthreshold \\
\hline \multirow[t]{7}{*}{ Organochlorines } & Perchlorethylene & n.d. & 2.1 & & \\
\hline & Trichlorotrifluroethane & n.d. & n.d. & & \\
\hline & Chlorodifluoromethane & n.d. & 48.7 & & \\
\hline & Trichlorodifluoromethane & 571.9 & 90.2 & 5620 & \\
\hline & Chloromethane & n.d. & n.d. & & \\
\hline & Dichloromethane & n.d. & 373.2 & 174,000 & \\
\hline & Trichloromethane & 940.5 & 19.7 & & \\
\hline Mercaptans & Methyl mercaptan & n.d. & n.d. & 980 & 1.1 \\
\hline \multirow[t]{2}{*}{ Sulfides } & Carbon disulfide & 142.7 & n.d. & 31,000 & 1306.0 \\
\hline & Dimethyldisulfide & n.d. & n.d. & & 7.7 \\
\hline \multirow[t]{3}{*}{ Ketones } & Butan-2-one & n.d. & n.d. & & 182,681 \\
\hline & Propanone & n.d. & 61.2 & & 147,160 \\
\hline & 3-methyl-3-buten-2-one & n.d. & n.d. & & \\
\hline \multirow{2}{*}{$\begin{array}{l}\text { Aliphatic } \\
\text { aldehydes }\end{array}$} & Hexanal & n.d. & n.d. & & \\
\hline & Heptanal & n.d. & $<$ d.l. & & \\
\hline \multirow[t]{3}{*}{ Aromatics } & Furfural & n.d. & 43.5 & 7900 & \\
\hline & Benzaldehyde & n.d. & n.d. & & \\
\hline & Hydroxybenzaldehyde & n.d. & n.d. & & \\
\hline \multirow[t]{2}{*}{ Aliphatic acids } & Acetic acid & n.d. & 25.9 & 25,000 & \\
\hline & 2-methyl prop & n.d. & n.d. & & \\
\hline \multirow[t]{2}{*}{ Aliphatic esters } & Methyl acetate & n.d. & n.d. & 606,000 & \\
\hline & Ethyl acetate & n.d. & 7.3 & & \\
\hline Terpens & $\alpha$-pinene & 24.5 & n.d. & & \\
\hline Linear aliphatic & n-pentane & n.d. & 120.3 & & \\
\hline
\end{tabular}




\begin{tabular}{|c|c|c|c|c|c|}
\hline Family & Species & $\begin{array}{l}0 \text { wt.\% } \\
\text { sludge }\end{array}$ & $\begin{array}{l}15 \text { wt. } \% \\
\text { sludge }\end{array}$ & $\begin{array}{l}\text { TLV- } \\
\text { TWA }\end{array}$ & OdourOdorthreshold \\
\hline \multirow[t]{8}{*}{ hydrocarbons } & n-hexane & n.d. & 25.9 & & \\
\hline & n-decane & 37.3 & 9.3 & & \\
\hline & n-undecane & 37.3 & 9.3 & & \\
\hline & n-dodecane & n.d. & 14.5 & & \\
\hline & n-tridecane & n.d. & 28.0 & & \\
\hline & n-tetradecane & n.d. & 34.2 & & \\
\hline & n-pentadecane & n.d. & 16.6 & & \\
\hline & n-hexadecane & n.d. & 5.2 & & \\
\hline \multirow{4}{*}{$\begin{array}{l}\text { Branched } \\
\text { aliphatic } \\
\text { hydrocarbons }\end{array}$} & 2,2-dimethyl-pentane & $10,693.3$ & 342.1 & & \\
\hline & Branched nonanes & n.d. & n.d. & & \\
\hline & Branched decanes & n.d. & n.d. & & \\
\hline & Branched undecanes & n.d. & n.d. & & \\
\hline \multirow{2}{*}{$\begin{array}{l}\text { Cyclic aliphatic } \\
\text { hydrocarbons }\end{array}$} & Methylcyclopentane & n.d. & n.d. & & 22,344 \\
\hline & Cyclohexane & n.d. & n.d. & & \\
\hline \multirow{6}{*}{$\begin{array}{l}\text { Monocyclic } \\
\text { aromatics }\end{array}$} & Benzene & 92.7 & n.d. & 32,000 & 194,712 \\
\hline & Toluene & 182.1 & 62.2 & 188,000 & 6024 \\
\hline & Ethylbenzene & n.d. & 7.3 & 434,000 & 2602 \\
\hline & m + p-xylene & 22.4 & 20.7 & 434,000 & 86,757 \\
\hline & o-Xylene & n.d. & 9.3 & & 86,757 \\
\hline & Styrene & n.d. & n.d. & 434,000 & 85,120 \\
\hline
\end{tabular}

${ }^{a}-<$ d.l. means that the value is under the detection limit of the measurement device; n.d. $\|=$ not detected.

The presence of dichloromethane (373.2 $\left.\mathrm{g} \mathrm{m}^{-3}\right)$ and propanone $\left(61.2 \mu \mathrm{g} \mathrm{m}^{-3}\right)$ in the samples with added sludge was relatively relevant in comparison with concentrations in samples made of $100 \%$ clay. All monocyclic aromatics detected showed a concentration level far below their edoufodorthreshold. In general, thus, it can be concluded that VOCs-VOC emissions during firing of the new ceramic material do not involve any particular problem.Outgassing and offgassing tests applied to this ceramic material gave negative results in all cases (see Table 10). They were always well below the limits for a material that could be installed inside a manned spacecraft. 


\subsection{Industrial experience}

The average annual production of clay bricks in Spain is 20.9 -Mt per year. In recent years these figures have suffered an important reduction, in the order of 20 to $40 \%$, due to the-adverse economic situation. Despite the unfavorable economic climate especially in the construction sector in terms of the production of clay bricks, the introduction of paper sludge in ceramic matrices provides promising results from an industrial perspective. It has been shown that the addition of up to $15 \mathrm{wt} \%$ of paper sludge allows the industrial production of structural and/or closure ceramics for the building sector.

The binary mixture of clay and paper sludge was used without difficulty despite the interstitial water content of the waste, provided that the sludge percentage is less than 20 wt.\%. A higher content of paper sludge would only be possible through a process of prior drying of sludge and/or even adding other types of industrial wastes mixed with paper sludge to absorb part of the water content, so that the mixture with clay could feasibly be extruded in conventional extruders. Crushed forest residues, building wastes properly shredded, aggregates, etc., with sizes from 50 to $100 \mu \mathrm{m}$, would be suitable to achieve paper sludge additions up to 25 wt.\%.

However, although the industrial production of ceramic products for construction incorporating a maximum of $10-15 \mathrm{wt} . \%$ of paper sludge has been successful in different EU countries, the process has not been widely implemented owing to several reasons, some of which will be analyzed below.

The authors studied the case of the Company Belianes Ceramics (located at Belianes, province of Lleida, $145 \mathrm{~km}$ from Barcelona). This company, dedicated to the manufacturing of clay bricks, has been for more than ten years incorporating $7 \mathrm{wt} \%$ paper sludge in their clay mixture to manufacture ceramics. This sludge originated from the paper company Gomá Camps SAU (Fig. 2), which supplies 700 -tonnes of paper sludge per year. This sludge has a net calorific value of $561 \mathrm{kcal} \mathrm{kg}^{-1}$ according to the CEA 1235 analysis method, and a 52.8 wt.\% of moisture content. The original interest of the company in the addition of sludge had to do with the associated reduction in the need of raw materials, while at the same time diminishing the supply of water for the preparation of slurry. Finally, the process could also take advantage of the small contribution of energy obtained from organic matter in the sludge. 


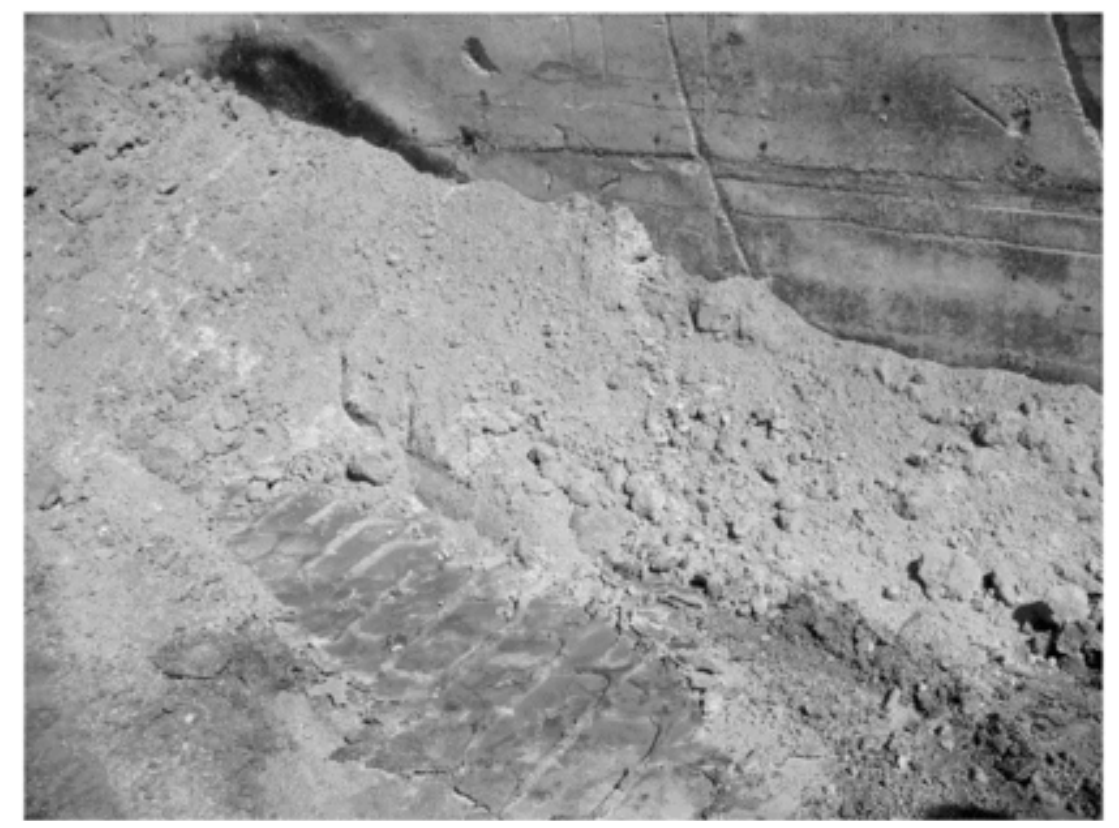

Fig. 2 Appearance of a semi-dehydrated sludge from the paper industry.

During the industrial production of the ceramics with additivated paper sludge, two types of unwanted side effects appear: a) the presence of white dots in the final product, which has to do with ashes produced from the cooking of the sludge, and were not related to the lime that exploded at the surface, and b) white-stained surface, which is associated to-with the lack of oxygen during cooking (Fig. 3). These are not critical defects for the final use and commercialization of the products, since these particular bricks are to be covered (with plaster or mortar) when used in building work.

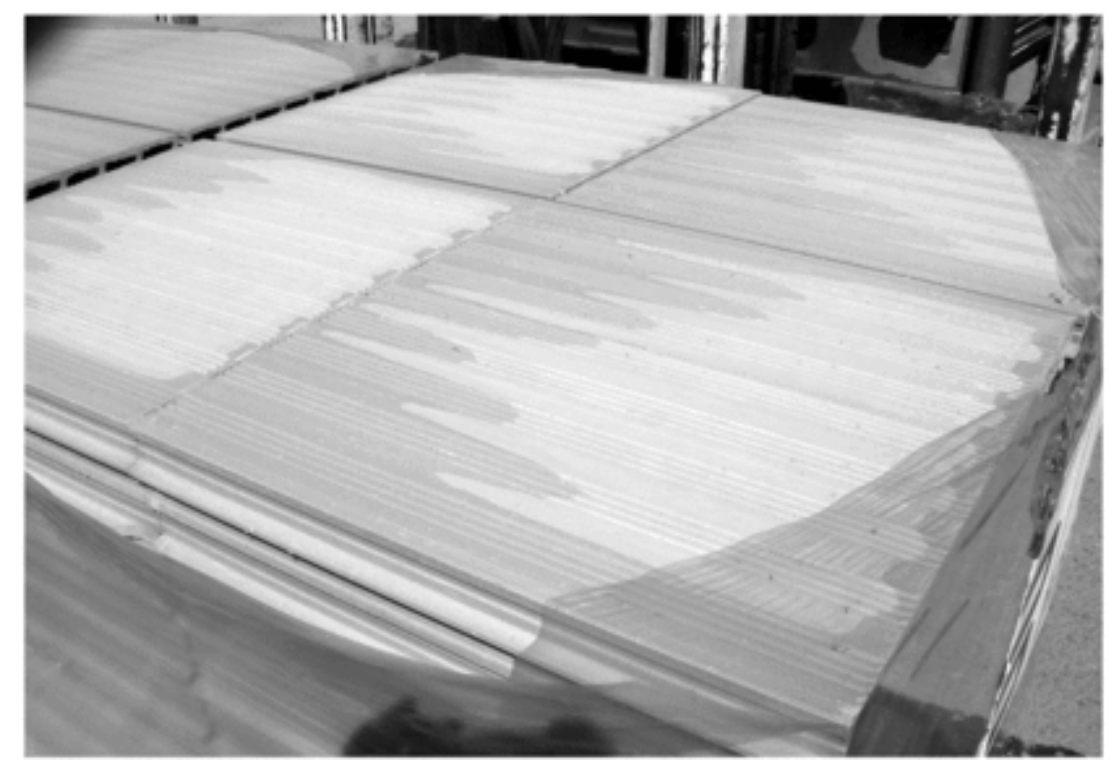

Fig. 3 Example of ceramic pieces made with addition of 13 wt.\% of sludge (with 58 wt.\% humidity) produced in a paper industry. The changes in color are probably due to the presence of kaolinite and calcite in the sludge. 
The authors were also acquainted of-with another company, Casa Ceramics SA, in Muel, Zaragoza, Spain, that since 2000 is also incorporating paper sludge into their production process. They reported an estimated energy reduction of $3 \%$ when adding sludge into their clay mixture.

This same company is currently investigating the possibility to add into their clay mixture not only paper sludge, but also grape seeds and micronized coking coal, in order to improve the calorific value of the mixture and decrease the energy cost in the economic balance of the ceramic production.

\section{Conclusions}

Use of sludge from the paper industry for the production of ceramic materials seems to be one of the few successful stories when trying to give answer to the challenging problem of recycling sewage sludge. Its incorporation into clay mixtures is quite common in various countries. Particularly, in Spain, almost all of the sludge produced by the paper industry is nowadays inertized as ceramic material for construction.

Increasing the paper sludge content in the clay mixture provides the material with improved properties regarding its thermal and acoustic insulation, but in turn it decreases its mechanical strength. However, this fragility of the material is compensated by an increased ductility, a property which may be an advantage when the ceramic material is to be used, for instance, for making gutters for wiring in buildings.

Clay brick production with incorporation of paper sludge waste is a feasible solution from the technical point of view because its implementation has the following advantages:

a)

Acceptable mechanical performance of the new material.

b)

Improvement in the thermal and acoustical isolating properties of the material.

c)

According to the results of the leaching tests, it has no restrictions for its use as building ceramics.

d)

No remarkable hazardous inorganic and VOCs-VOC emissions during firing.

e)

The final ceramic product is of a similar quality as conventional ceramics. 
Finally, the use of industrial waste, such as is the case of paper sludge presented in this paper, can significantly economize the price of building materials (since waste sludge is used as a raw material at zero cost) and might represent a sound solution towards the minimization of the environmental impact of waste from the paper industry.

\section{Appendix A}

Basic leaching tests consist of submerging the sample into distilled water, and measuring the concentration of inorganic components during different time intervals. A short description of the method followed (EN-12457-1) is given here. Prepare a test portion of mass $175 \pm 5 \mathrm{~g}$ and place it in a bottle (HDPE/PP, caps by Teflon), add leachant (distilled water), 2:1 liquid:solid. Testing conditions should be $20 \pm 5^{\circ} \mathrm{C}$. Mix for $24 \mathrm{~h}$ in an end-over-end drum tumbler (5-10 rpm) or use a roller table. After $24 \mathrm{~h}$ allow to settle for $15 \mathrm{~min}$. Filter without rinsing (centrifuge if necessary), measure volume of filtered eluate (conductivity, temperature and $\mathrm{pH}$ of eluate can be measured). Analysis of leachates was carried out by inductively coupled plasma atomic emission spectrometry (ICP-AES THERMO JARRELL-ASH 61E Polyscan). The completed testing procedure, the elements that were measured and the specific techniques that were used in the tests can be found in Cusidó and Cremades (2012).

Pollutant concentrations and emission parameters were obtained accordingto the corresponding EPA standard for each case (EPA: 1, 2, 4, 5, 26, 13B, 25 and 29). For the determination of the concentration of sulfur dioxide, carbon monoxide, carbon dioxide and nitrogen oxides, equipment approved by TÜV following DIN standards (Cusidó et al., 2003) was used. The list of equipment used in the tests was:

Isokinetic probe NAPP PM-100 (Millenium Instruments Inc., USA) equipped with a Pyrex tube, for measuring gas velocity

Equipment for continuous control of gases: $\mathrm{CO}, \mathrm{CO}_{2}, \mathrm{SO}_{2}, \mathrm{NO}, \mathrm{NO}_{2}, \mathrm{NO}_{x}, \mathrm{O}_{2}$, TESTO 360 (Testo AG, Germany), for measuring concentrations

TEDLAR bags (Supelco, USA) equipped with flow regulation, for air sampling.

Opacimeter BRIGON (Brigon Messtechnik, Germany), for measuring particle concentration 
Gas chromatograph Hewlett-Packard HP-5890 Series A equipped with athermicalthermal conductivity detector (Hewlett-Packard, USA), for screening, identification and quantification of air pollutants.

For comparative purposes, tests were conducted both with conventional ceramics (as sample blank) and with ceramics with 15 wt.\% sludge.

Due to the presence of organic matter in the binary mixture, it was also necessary to identify and quantify the concentration of volatile organic compounds (VOCs) in the emitted gases during the industrial production of the new ceramic material. Measurements were obtained through thermal desorption linked to gas chromatography with mass selective detector (TD_-GC_-MS). The list of equipment used in the tests was the following:

Flowmeter Jour Digital calibrated, $0.1 \_-500 \mathrm{ml} \mathrm{min}=1$.

Air suction pump, ESCORT ELF with air sampler Gemini Twin-Port, suction flow between 0.5 and $31 \mathrm{~min}^{-1}$.

Pyrex glass tubes (two per sample), Perkin-Elmer, filled with a sandwich of three adsorbers: Carbotrap (100 g), Carbotrap C (100 g) and Carbosierve III (100 g), interspersed with glass wool Panreac.

Equipment for thermal desorption Perkin-Elmer, model ATD-400, provided with a carousel for 50 samples.

Gas chromatograph Hewlett-Packard model 5890 series II with mass detector.

Digital precision scales Mettler models AJ100 and PJ400.

The methodology followed to perform the tests is described below:

a)

Tubes with the adsorbers were preconditioned according to the manufacturer's specifications: $250{ }^{\circ} \mathrm{C}$ (30 min), $300^{\circ} \mathrm{C}$ (30 min), $325^{\circ} \mathrm{C}(30 \mathrm{~min})$ and $350{ }^{\circ} \mathrm{C}(30 \mathrm{~min})$.

b) 
Two adsorption tubes were joined together in series using Teflon tubing (which moisture had been previously removed). The free end of the second tube was connected to a low flow pump (100 $\left.\mathrm{ml} \mathrm{min}^{-1}\right)$. Sampling time was 6 hoursh.

c)

Desorption and analysis of sampling tubes was-were carried out in a thermal desorber, which was connected to a gas chromatograph equipped with a mass selective detector through a transfer line $\left(200^{\circ} \mathrm{C}\right)$. The trapped compounds were desorbed at $290{ }^{\circ} \mathrm{C}$ for 10 minutesmin at the pressure of the carrier gas (He) of about 11.5 psi, with splits in and out of desorber set to 0 and $5 \mathrm{ml} \mathrm{min=1}$, respectively. The cold trap (quartz tube with $20 \mathrm{mg}$ of Carbotrap C) was maintained at-_- $30^{\circ} \mathrm{C}$ initially and was heated to $290{ }^{\circ} \mathrm{C}$ for $3 \mathrm{~min}$. The separation of compounds was carried out using a capillary column (J\&W Scientific, DB-5) using He as carrier gas at a rate of $0.5 \mathrm{ml} \mathrm{min=1}$.

d)

For the qualitative analysis, peaks observed in the chromatogram were compared with those stored in the NBS spectra library.

e)

In the quantitative analysis the external standard method was followed. The standard solution was injected into the tube to be analyzed under the same conditions as those present during the sampling tubes. They consisted of a mixture composed of organochlorine compounds (dichloromethane, trichloromethane and trichloroethene), aromatic compounds (benzene, toluene, ethylbenzene and m-xylene), a sulfide compound (methyl sulfide) and a nitrogen compound (pyridine). Each VOC found in the samples was quantified according to the response factor of the most similar compound of the standard solution.

f)

The second tube of each pair of samples was the first to be analyzed, in order to make sure that all VOCs were hold mostly in this first tube. Quantification was done by adding the retention times observed in the two tubes of each pair.

\section{References}

American Industrial Hygiene Association, 1989. Odor thresholds for chemicals with established occupational health standards. Akron, Ohio. APHA, Métodos normalizados para el análisis de aguas potables y residuales, 1992, APHA_AWWAWPCF (American Public Health Association__American Water Works AssociationWater Pollution Control Federation); Ediciones Díaz de Santos, S.A., Madrid, (in Spanish). 
Asquini L., Furlani E., Bruckner S. and Maschio S.D., Production and characterisation of sintered ceramics from paper mill sludge and glass cullet,Chemosphere 71, 2008, 8389.

Berman N.A., Brick: an Innovative Sludge Solidification Process, (Master Thesis)1982, Maryland University; USA.

Brownell W.E., Structural Clay Product, 1976, Springer-Verlag; Wien-New York.

Cernec F., Zule J., Moze A. and Ivanus A., Chemical and microbiological stability of waste sludge from paper industry intended for brick production, Waste Manag. Res. 23 (2), 2005, 106-112.

Chemani B. and Chemani H., Utilization of paper sludge in clay bricks industry to obtain lightweight material: evidence from partial replacement of feldspar by paper sludge, Int. J. Phys. Sci. 8 (9), 2013, 335-342.

Chiang K.-Y., Chou P.-H., Hua C.-R., Chien K.-L. and Cheeseman C., Lightweight bricks manufactured from water treatment sludge and rice husks, J. Hazard. Mater. 171, 2009, 76-82.

Council Directive 99/31/EC of 26 April 1999.

Cusidó J.A. and Cremades L.V., Environmental effects of using clay bricks produced with sewage sludge: leachability and toxicity studies, Waste Manag. 32, 2012, 1202-1208.

Cusidó J.A., Cremades L.V. and González M., Gaseous emissions from ceramics manufactured with urban sewage sludge during firing processes, Waste Manag. 23, 2003, 273-280.

Demir I., Serhat Baspinar M. and Orhan M., Utilization of kraft pulp production residues in clay brick production, Build. Environ. 40, 2005, 1533-1537.

Devant M., Cusidó J.A. and Soriano C., Custom formulation of red ceramics with clay, sewage sludge and forest waste, Appl. Clay Sci. 53, 2011, 669-675.

El Yakoubi N., Aberkan M. and Ouadia M., Potentialité d'utilisation d'argiles marocaines de Jbel Kharrou dans l'industrie céramique, C. R. Geosci. 338 (10), 2006, 693-702, (in French).

EN 12457-_1, Characterization of waste, Leaching: Compliance Test for Leaching Of Granular Waste Materials and Sludges, 2002, European Union standard.

EPA, New Source Performance Standards (NSPS), Code of Federal Regulations, 40 CRF 60, 1994, Environmental Protection Agency; Washington. 
Hajjaji M. and Kacim S., Clay__calcite mixes: sintering and phase formation, Br. Ceram. Trans. 103 (1), 2004, 29-32.

Ismail M., Ismail M.A., Lau S.K., Muhammad B. and Majid Z., Fabrication of bricks from paper sludge and palm oil fuel ash, Concr. Res. Lett. 1 (2), 2010,60-66.

Jordan M.M., Almendro-Candel M.B., Romero M. and Rincón J.M., Application of sewage sludge in the manufacturing of ceramic tile bodies, Appl. Clay Sci. 30, 2005, 219-224.

Kaosol T., Reuse water treatment sludge for hollow concrete block manufacture,Energy Res. J. 1 (2), 2010, 131-134.

Lee H.S. and Bae S.K., Combustion kinetics of sewage sludge and combustible wastes, $J$. Mater. Cycles Waste Manage. 11, 2009, 203-207.

Liew A.G., Idris A., Samad A.A., Wong C.H.K., Jafafar M.S. and Baki A.M.,Reusability of sewage sludge in clay bricks, J. Mater. Cycles Waste Manage. 6, 2004, 41-47.

Likon M. and Trebse P $\underline{P}$., Recent Advances in Paper Mill Sludge Management in Industrial Waste, In: Show Kuan-Yeow and Guo Xinxin, (Eds.), 2012,ISBN: 978-953-51-0253363-90.

Lin D.-F. and Weng C.-H., Use of sewage sludge ash as brick material, J. Environ. Eng. 127, 2001, 922-927.

Loutou M., Hajjaji M., Mansori M., Favotto C. and Hakkou R., Phosphate sludge: thermal transformation and use as lightweight aggregate material, J. Environ. Manag. 130, 2013, 354-360.

Maschio S., Furlani E., Tonello G., Faraone N., Aneggi E., Minichelli D., Fedrizzi L.,Bachiorr ini A. and Bruckner S., Fast firing of tiles containing paper mil sludge, glass cullet and clay, Waste Manag. 29 (11), 2009, 2880-2885.

Monte M.C., Fuente E., Blanco A. and Negro C., Waste management from pulp and paper production in the European Union, Waste Manag. 29, 2009,293-308.

Monteiro S.N. and Vieira C.M.F., Effect of oily waste addition to clay ceramics,Ceram. Int. 31, 2005, 353-358.

Monteiro S.N., Alexandre J., Margem J.I., Sánchez R. and Vieira C.M.F.,Incorporation of sludge waste from water treatment plant into red ceramic,Constr. Build. Mater. 22, 2008, 1281-1287.

Montero M.A., Jordán M.M., Hernández-Crespo M.S. and Sanfeliu T., The use of sewage sludge and marble residues in the manufacture of ceramic the tile bodies, Appl. Clay Sci. 46, 2009, 404-408. 
Mymrin V., Ferreira A.M.C., Gardolinski J.E., Guimaraes B. and OkimotoM.L.L.RM.L.L.R., Paper production sludge application for producing of new construction materials, In: Proc. of the 11th International Conference of Non-conventional Materials and Technologies (NOCMAT 2009), 6-9 Sept. 2009, Bath, UK, 2009.

Pera J. and Amrouz A., Development of highly reactive metakaolin from paper sludge, Adv. Cem. Based Mater. 7 (2), 1998, 49-56.

Pera J., Ambroise J., Biermann J. and Voogt NN., Use of thermally converted residue as a building material, In: Proc. of the 3rd CANMET/ACI Int. Symp. on Sustainable Development of Cement and Concrete, San Francisco, 16_-19 Sept. 2001, San Francisco, 2001, 111-123.

Qi Y., Yue Q., Han S., Yue M., Gao B., Yu H. and Shao T., Preparation and mechanism of ultra-lightweight ceramics produced from sewage sludge, J. Hazard. Mater. 176, 2010, 76-84.

Salomãoa R., Villas Bôasa M.O.C. and Pandolfelli V.C., Porous alumina-spinel ceramics for high temperature applications, Ceram. Int. 37 (4), 2011,1393-1399.

Sutcu M. and Akkurt S., The use of recycled paper processing residues in making porous brick with reduced thermal conductivity, Ceram. Int. 35 (7), 2009,2625-2631.

Tang F., Fudouzi H. and Sakka Y., Fabrication of macroporous alumina with tailored porosity, J. Am. Ceram. Soc. 86 (12), 2003, 2050-2054.

Tay J.-H., Bricks manufactured from sludge, J. Environ. Eng. 113 (2), 1987,278-283.

Toya T., Kameshima Y., Nakajima A. and Okada K., Preparation and properties of glassceramics from kaolin clay refining waste (Kira) and paper sludge ash,Ceram. Int. 32 (7), 2006, 789-796.

UNE 67-026-94, Ladrillos y bloques cerámicos de arcilla cocida. Determinación de la resistencia a compresión, Experimental standard, 1994, (in Spanish).

Van der Sloot H.A., European Activities on Harmonization of Leaching-/-Extraction Test and Standardisation in Relation to the Use of Alternative Materials in Construction, 2001, ICMAT International Conference on Materials for Advanced Technologies; Singapore.

Vigil de la Villa R., Frías M., Sánchez de Rojas M.I., Vegas I. and García R.,Mineralogical and morphological changes of calcined paper sludge at different temperatures and retention in furnace, Appl. Clay Sci. 36, 2007,279-286. 
Wiebusch B., Ozaki M., Watanabe H. and Seyfried C.F., Assessment of leaching tests on construction material made of incinerator ash (sewage sludge). Investigations in Japan and Germany, Water Sci. Technol. 38 (7), 1998,195-205 